Seminário de Pesquisa

Programa de Pós-Graduação

Design FAU USP

\title{
Além e Aquém da Tela: Possibilidades espaciais da imagem eletrônica e o design de audiovisual como instrumento de projeto
}

\author{
Luís Felipe Abbud, Giselle Beiguelman
}

design de audiovisual; imagem eletrônica; imagem técnica; realidade estendida; design de imersão

Esta pesquisa explora o design de audiovisual como campo para problematização da imagem eletrônica, e o modo com o qual diferentes formas de experiência da cidade contemporânea podem ser mediadas por ela. Tem como tônica a análise da espacialidade que emerge da realidade estendida (conjunto de tecnologias composto pelas realidades virtual, aumentada e mista). Para tanto,

Curso

Doutorado

\section{Linha de Pesquisa}

Design: Processos e Linguagens

\section{Luís Felipe Abbud}

Graduado em arquitetura e urbanismo (2003-10) e doutorando em de design (2019-) pela FAUUSP, é professor da Associação Escola da Cidade (São Paulo, 2016-) e fundador do estúdio NúMENA, onde atua em projetos locais e internacionais integrando os diferentes campos de arquitetura, design e audiovisual.

e-mail: luis.abbud@usp.br Lattes: http://lattes.cnpq. br/0574026668649351

Orcid: https://orcid.org/00000002-6162-0655

\section{Giselle Beiguelman}

Artista, Professora da FAUUSP e coordenadora do GAIA, Grupo de Arte e Inteligência Artificial InovaUSP. Autora de diversos livros e artigos sobre arte, cultura digital e estéticas da memória no século 21. Suas obras integram acervos de museus internacionais. É colunista da RádioUSP e da RevistaZum e-mail: gbeiguelman@usp.br Lattes: http://lattes.cnpq. br/4120752125995822

Orcid: https://orcid.org/00000003-4812-5972 investiga as formas de intersecção entre os espaços virtual (por imagens eletrônicas programadas) e real efetivamente construído e investiga como o campo do design passa a efetivamente configurar espaços híbridos de habitabilidade, unindo design gráfico (interfaces de usuários para programas e aplicativos), de objeto (dispositivos tecnológicos nos quais operam para criação de experiências imersivas) e de experiência (programação de jogos, aplicativos e plataformas digitais). A discussão é estruturada a partir da exposição Máquina Olho (Campinas,2019), realizada pelo autor desta pesquisa, como projeto-base para coletânea e organização de conhecimento sobre a arqueologia da imagem técnica. A pesquisa, metodologicamente afinada com as práticas de research by design, terá como produto final um conjunto de aplicações das tecnologias abordadas, por meio de processos de visualização de dados e uma nova edição da exposição Máquina Olho em espaço on-line imersivo. A pesquisa se baseia na coletânea de dados extraídos de fontes heterogêneas referentes ao universo estudado (bibliográficas, videográficas e webgráficas), e na padronização sistêmica dessas informações em modelos visuais 2D e 3D. Tal sistema tem como objetivo a geração de quadros comparativos em escala, a partir dos quais será possível realizar as análises pretendidas, bem como tornar seus produtos acessíveis no formato expositivo proposto. 


\title{
Beyond and Before the Screen: Spatial possibilities of electronic image and the audiovisual design as instrument of project
}

\author{
Luís Felipe Abbud, Giselle Beiguelman
}

\author{
audiovisual design; electronic image; technical image; extended \\ reality; immersion design
}

This research explores audiovisual design as a field for problematizing electronic image, and the way in which different forms of experience in the contemporary city can be mediated by this design. The research focuses on the analysis of the relations of spatiality that emerge from extended reality experiences (set of technologies composed of virtual, augmented and mixed realities); their respective forms of intersection between virtual spaces (by programmed electronic images) and real and effectively constructed spaces; and analysis of how the design field configures hybrid spaces for habitability, combining graphic design (user interfaces for programs and applications), object design (technological devices in

Course

Doctoral

\section{Line of Research}

Design: Processes and Languages

\section{Luís Felipe Abbud}

Graduated in architecture and urbanism (2003-10) and doctorate in design (2019-) by FAUUSP, he is a teacher at Associação Escola da Cidade (São Paulo, 2016-) and founder of NúMENA studio, working in local and international projects integrating different fields of architecture, design and audiovisual

e-mail: luis.abbud@usp.br Lattes: http://lattes.cnpq. br/0574026668649351

Orcid: https://orcid.org/00000002-6162-0655

\section{Giselle Beiguelman}

Artist, Professor at FAUUSP and coordinator of GAIA, Art and Artificial Intelligence Group InovaUSP. Author of books and articles on art, digital culture and aesthetics of 21st century's memory. Her works are part of international museum collections, and is a columnist for RádioUSP and RevistaZum.

e-mail: gbeiguelman@usp.br

Lattes: http://lattes.cnpq. $\mathrm{br} / 4120752125995822$

Orcid: https://orcid.org/00000003-4812-5972 which they operate to create immersive experiences) and experience design (programming of games, applications and digital platforms). The discussion is structured from the exhibition Maquina Olho (Campinas,2019), designed by the author of this research, as a base project for the collection and organization of knowledge about the archeology of the technical image. The research, methodologically in line with the practices of research by design, will have as a final product a set of applications of the technologies studied, through data visualization processes and a new edition of the exhibition Maquina Olho in an immersive online space. The research is based on the collection of data extracted from heterogeneous sources (bibliographic, videographic and webgraphic) referring to the studied universe, and on the systemic standardization of this information in $2 \mathrm{D}$ and $3 \mathrm{D}$ visual models. This system aims to generate comparative tables in scale, from which the desired analyzes will be developed, and its products will be accessible through the proposed exhibition format.

\section{Referências | References}

CRARY, J. 2012. Técnicas do observador: visão e modernidade no século XIX. Rio de Janeiro: Contraponto.

DUBOIS, P. 2004. Máquinas de imagens: uma questão de linha geral. In: DUBOIS, P. Cinema, Video, Goddard. São Paulo: Cosac Naify.

FLUSSER, V. 1985. Filosofia da caixa preta: ensaios para uma futura filosofia da fotografia. São Paulo: Editora Hucitec.

FRIEDBERG, A. 2006. The Virtual Window - From Alberti to Microsoft. Cambridge: MIT Press.

GRAU, 0. 2007. Arte visual: da ilusão à imersão. São Paulo: Editora UNESP. 